Інноватика у вихованні. Випуск 12. 2020.

УДК 378.14:373.211.24

DOI: $\underline{10.35619 / \text { iiu.v1i12.293 }}$

Шадюк Ольга

кандидат педагогічних наук, доцент, доцент кафедри педагогіки та психології (дошкільної та корекційної) імені проф. Т. І. Поніманської Рівненського державного гуманітарного університету, м. Рівне, Україна ORCID: 0000-0001-6120-7759, e-mail: olgapad@ukr.net

\title{
ГОТОВНІСТЬ МАЙБУТНІХ ВИХОВАТЕЛІВ ДО РОБОТИ 3 ДІТЬМИ РАННЬОГО ВІКУ
}

Анотація: У статті теоретично обгрунтовується проблема підготовки майбутніх вихователів до професійної діяльності, зокрема до роботи із дітьми раннього віку. Розглянуто сучасні підходи до професійної та дошкільної освіти. Визначено та уточнено сутність понять «професійна підготовка» та «готовність». Аналізуються особливості викладання дисципліни «Педагогіка раннього дитинства» для здобувачів першого рівня вищої освіти спеціальності 012 «Дошкільна освіта».

Одним із пріоритетних напрямів модернізації та оновлення дошкільної освіти виступає вдосконалення підготовки педагогічних кадрів, зокрема вихователів для закладів дошкільної освіти. На сучасному етапі розвитку суспільства для професійній освіті стала особливо актуальною проблема пошуку шляхів розвитку і вдосконалення системи підготовки педагогічних кадрів для роботи в сучасному закладі дошкільної освіти, а особливо для роботи 3 дітьми раннього віку. Формування готовності майбутніх вихователів до роботи з дітьми раннього віку буде найрезультативнішим в процесі вивчення дисципліни «Педагогіка раннього дитинства», яка забезпечує комплексний підхід до формування у студентів певних знань та практичних вмінь щодо роботи 3 дітьми раннього віку.

Ключові слова: готовність, здобувач вищої освіти, майбутні вихователі, діти раннього віку, професійна підготовка.

Постановка проблеми. Україні на сучасному етапі iї розвитку потрібні фахівці дошкільного профілю нової формації 3 конкурентно придатним європейським чи світовим рівнем кваліфікації для досягнення єдиної мети формування гармонійно розвиненої особистості. Нові реалії, орієнтація українського суспільства на демократичні принципи, реорганізація системи дошкільної освіти (зміна співвідношення родинного і суспільного дошкільного виховання, урізноманітнення його форм, багатоваріантність освітньо-виховних програм) зумовлюють необхідність змін і в системі підготовки фахівців дошкільної освіти (Куліш, 2014).

Слід зазначити, що на сучасному етапі розвитку дошкільної освіти значна увага приділяється проблемі професійної підготовки вихователя сучасного закладу дошкільної освіти, бо саме від нього залежить успішність процесу виховання, навчання та розвитку дітей дошкільного віку. Зважаючи на це,

(C) Шадюк О., 2020 
пріоритетним завданням підготовки здобувачів вищої освіти є формування у них таких професійних якостей, які забезпечать розуміння особистості та орієнтацію на розвиток і саморозвиток індивідуальності вихованця.

3 огляду на сучасні вимоги, виокремлюємо одне із завдань професійної освіти - пошук шляхів розвитку та вдосконалення системи підготовки здобувачів вищої освіти за спеціальністю 012 «Дошкільна освіта», зокрема для роботи $з$ дітьми раннього віку. Умови глобальної конкуренції на ринку праці вимагають від педагогів дошкільного виховання високого рівня професійної компетентності.

Аналіз основних досліджень 3 проблеми. Сучасні дослідження, які висвітлюють різні сторони підготовки здобувачів вищої освіти за спеціальністю 012 «Дошкільна освіта», представлені в роботах А. Аніщук (підготовка майбутніх вихователів до роботи 3 дітьми в умовах інклюзивної освіти); Г.Бєлєнької (формування фахової компетентності); Т. Величко (підготовка майбутніх вихователів до формування ціннісних орієнтацій у дошкільників); А. Залізняк (підготовка майбутніх вихователів до роботи 3 батьками); Л. Зданевич (підготовка майбутніх вихователів до роботи 3 дезадаптованими дітьми); Н. Лисенко, З. Плохій (підготовка вихователів до організації екологодослідницької діяльності дітей в природі); І. Луценко (підготовка майбутніх вихователів до організації комунікативно-мовленнєвої діяльності дошкільників); Н. Грама (теоретико-методичні засади фахової підготовки педагога-вихователя дошкільного закладу до економічного виховання дітей); Р.Куліш (підготовка майбутніх фахівців дошкільної освіти до професійної діяльності); А. Чаговець (сучасна професійна підготовка майбутніх вихователів дошкільних навчальних закладів); Г. Коріна (сучасні дослідження проблеми професійної підготовки майбутніх фахівців дошкільної освіти); І. Підлипняк (підготовка майбутніх фахівців дошкільної освіти); Н. Сайко (підготовка майбутніх вихователів до соціалізації дітей дошкільного віку).

Мета статті - висвітлити проблеми підготовки майбутніх вихователів до професійної діяльності, зокрема до готовності працювати із дітьми раннього віку.

Виклад основного матеріалу дослідження. Процеси реформування та модернізації, які зараз відбуваються в системі вищої педагогічної освіти, об'єктивно спрямовані на іiі подальший прогресивний розвиток, забезпечення потреб суспільств та держави кваліфікованими фахівцями, що передбачає відповідні зміни у професійно-педагогічній підготовці фахівців до роботи 3 дітьми дошкільного віку (Куліш, 2014).

У нашому дослідженні щодо підготовки майбутніх вихователів до роботи 3 дітьми раннього віку, ми спиралися на визначення поняття професійної підготовки Т. Танько, яка зазначала, що професійна підготовка - це система організаційних та педагогічних заходів, які забезпечують формування в особистості професійної спрямованості, системи знань, навичок, умінь і професійної готовності, що, в свою чергу, визначається як суб'єктивний стан особистості, яка вважає себе здатною і підготовленою до виконання певної професійної діяльності та прагне її виконати (Танько, 2004).

На сучасному етапі розвитку дошкільної освіти підготовка майбутніх вихователів розглядається як багатофакторна структура. Завданням цієї структури є набуття кожним здобувачем вищої освіти особистісного смислу 
діяльності, формування професійної майстерності та інтересу до роботи з дітьми дошкільного віку та їхніми батьками.

Проаналізувавши напрацювання сучасних досліджень, можемо констатувати, що професійне становлення майбутнього вихователя передбачає не лише оволодіння сукупністю знань, умінь та навичок, але і їхнє особистісне самовдосконалення, формування педагогічних цінностей, становлення професійної позиції, виховання таких якостей, як комунікативність, креативність, тактовність тощо.

Слід зазначити, що рівень підготовки майбутнього вихователя до роботи 3 дітьми раннього віку визначається сформованістю необхідних знань, умінь і навичок. Саме тому необхідно забезпечити оволодіння здобувачами вищої освіти знаннями 3 дошкільної педагогіки, дитячої психології, індивідуальних психологічних характеристик, вікової фізіології, педіатрії та гігієни, правил охорони життя і зміцнення здоров'я дітей.

Ми погоджуємось із твердженням Т. Поніманської, яка доводить, що особистісно орієнтована модель освіти висуває до сучасного вихователя високі вимоги, зокрема до його особистісного, професійного розвитку, комунікативних умінь і навичок, особливо до уміння бути активним учасником особистісноорієнтованого спілкування. Також дослідниця виділяє особистісні якості, якими повинен володіти вихователь, а саме: здатність до рефлексії, здатність виявляти і враховувати інтереси дітей, їхнє право на повагу, емоційно i морально підтримувати їх, прагнення до емоційної близькості у спілкуванні з ними, уміння спрямовувати його на забезпечення психологічного комфорту i своєчасного розвитку особистості; постійна налаштованість на розширення знань, самонавчання і самовиховання для вдосконалення своєї педагогічної майстерності (Поніманська, 2012).

Результатом підготовки $є$ готовність, яка трактується як настанова, спрямована на виконання якоїсь дії. Готовність $є$ важливою умовою успішного виконання педагогічної діяльності.

Отже, у роботах учених (А. Ліненко, О. Мороз та ін.) переконливо доведено, що саме стан готовності особистості до виконання професійно-педагогічної діяльності забезпечує не тільки їі ефективність, але й можливості подальшого вдосконалення. Тобто, підготовка стає засобом формування готовності до діяльності, а готовність є результатом і показником якості підготовки. Такого ж підходу дотримується Т. Жаровцева, «готовність», на іiі думку, - це мета i результат підготовки (Жаровцева, 2006).

Готовність майбутніх вихователів до роботи 3 дітьми раннього віку становить основу фахової підготовки до майбутньої педагогічної діяльності та потребує створення ефективної системи цієї підготовки. Фахова підготовка здобувачів вищої освіти за спеціальністю 012 «Дошкільна освіта» грунтується на освітньо-професійній програмі «Дошкільна освіта» i яка $\epsilon$ основою для планування й організації навчального процесу закладу вищої освіти, забезпечуючи поступову трансформацію пізнавальної діяльності у професійно спрямовану. Варто наголосити, що готовність майбутніх фахівців дошкільної освіти до роботи 3 дітьми раннього віку стане вищою за умови, якщо в процесі навчання у закладі вищої освіти належна увага буде зосереджена на практиках своєрідності і специфіки педагогічної діяльності вихователя.

Важливо наголосити на тому, що заклади вищої освіти оновлюють зміст навчально-виховної підготовки майбутніх фахівців 3 педагогічних дисциплін 
відповідно до сучасних Стандартів та теоретико-методологічних концепцій особистісно-діяльнісного підходу. У цьому контексті передбачено ознайомлення студентів 3 альтернативними виховними системами та педагогічними інноваціями. Професійна підготовка майбутніх фахівців дошкільної освіти спрямовується на вдосконалення плану освітнього процесу, зокрема удосконалення циклу професійної підготовки.

Опрацювавши низку наукових праць, ми дійшли висновку, що основне завдання у формуванні готовності здобувачів вищої освіти до педагогічної взаємодії з дітьми раннього віку, - це сформованість у майбутніх вихователів закладів дошкільної освіти усвідомленої професійної активності та розуміння усвідомлення ними мотиву, мети, траєкторії своєї активності, способів іiі використання при педагогічній взаємодії з дітьми раннього віку.

Варто зазначити, що ранній вік - це унікальний період розвитку дитини, який відрізняється низкою особливостей і надзвичайно важливо, аби у цей період поруч із дитиною був справжній спеціаліст, який знає свою справу i допоможе дитині розвиватися найшвидшими темпами. Адже для цього віку характерний швидкий темп фізичного і психічного розвитку.

Професійні знання вихователя в роботі з дітьми раннього віку охоплюють надзвичайно широкий спектр - від пізнання закономірностей та особливостей психолого-педагогічного розвитку дітей, знання вікових та індивідуальних можливостей, аж до діагностики результатів впливу виховних дій на дітей раннього віку.

У сучасному закладі вищої освіти процес підготовки майбутніх вихователів увійшов у новий етап, зумовлений тим, що у пріоритеті стає реалізація компетентнісного підходу при підготовці фахівців до роботи 3 дітьми раннього віку. Проте, варто зазначити, що нині, немає окремої системи професійної підготовки майбутніх вихователів до роботи із дітьми раннього віку. При цьому очевидним $\epsilon$ те, що основою такої педагогічної діяльності має стати навчання взаємодії майбутнього вихователя 3 дітьми раннього віку в спеціально організованих умовах, які уможливлять: створення мотивації, формування необхідних знань та вмінь, оволодіння методиками навчально-виховної роботи 3 дітьми раннього віку, організацію спеціальної педагогічної практики для роботи 3 дітьми раннього віку.

Ми схиляємося до думки про те, що взаємодія вихователя 3 маленькою дитиною за особистісно орієнтованою моделлю сприяє тому, що дитина вчиться почувати себе упевнено, не боятися помилок; поважати себе та інших, бути щирою, думати самостійно, адекватно виражати свої почуття, розуміти i співчувати іншим. Тому надзвичайно важливо підготувати майбутнього вихователя до такої складної діяльності.

Готуючи майбутнього вихователя до роботи 3 дітьми раннього віку, слід пам'ятати, що сучасний вихователь зобов'язаний: володіти культурою спілкування і культурою мовлення; добре знати вікові особливості дітей раннього віку, мати уявлення про психологічні закономірності розвитку дитини на різних вікових етапах; мати відповідні навички догляду за дітьми раннього віку; знати сучасні освітні програми для дітей раннього віку; уміти організовувати ігрову діяльність дітей.

Ми переконані також у тому, що особливістю роботи з дітьми раннього віку $\epsilon$ i те, що вихователь мусить спиратися на практичні дії дитини в конкретній ситуації. Адже, мислення і мова дитини завжди пов'язані з іiі безпосереднім 
досвідом. Не можна забувати про безпосередність та емоційність дітей раннього віку. Саме ці особливості дітей раннього віку диктують особливі вимоги до діяльності вихователя.

Для реалізації усіх зазначених нами завдань готовності майбутнього вихователя до роботи 3 дітьми раннього віку в освітній план спеціальності 012 «Дошкільна освіта» була введена дисципліна «Педагогіка раннього дитинства», яка викладається здобувачам вищої освіти на другому курсі напередодні практики в групах дітей раннього віку.

Силабус курсу передбачає ознайомлення майбутніх вихователів із загальними засадами педагогіки раннього дитинства, змістом та методами виховання дітей раннього віку та організаційно-методичною роботою в групах дітей раннього віку.

3 метою ефективної роботи на практичних та лабораторних заняття для фахівців зі спеціальності 012 «Дошкільна освіта» був розроблено робочий зошит, що містить: методичні рекомендації щодо самостійної роботи здобувачів вищої освіти; система, вимоги та критерії оцінювання результатів навчання; розподіл балів, що отримують здобувачі вищої освіти; теми практичних занять із планом, завданнями для самостійної роботи та рекомендованим переліком літературних джерел; перелік питань до екзамену та тести.

Під час роботи на практичних заняттях студентам було запропоновано завдання для роздумів, які допомагали їх змоделювати свою майбутню професійну діяльність в групах дітей раннього віку, наприклад: «Запропонуйте способи ранкового залучення тих дітей, які не відпускають мам, намагаються залишитися 3 ними, відмовляються йти в групу», «Складіть режим дня для дітей 3-го року життя та доведіть його доцільність», вирішіть педагогічну задачу «Малюки будують потяг для ляльок. Спочатку вони беруть кубик (паровоз), потім по одній цеглинці (вагончики). Далі кожен малюк садить свою ляльку у свій вагончик так, щоб у кожному вагончику було по одній ляльці. Несподівано один хлопчик починає стукати лялькою. Педагог каже: «Лялька у вагончику не повинна стрибати!». Почувши іiі слова, всі діти починають стукати своїми ляльками, примовляючи: «Ляльки стрибають, танцюють». Вихователька розгубилася, не знаючи, як припинити стукіт. Поясніть причину такої поведінки дітей. Як бути вихователю в такій ситуації?».

Було також запропоновано багато завдань, що передбачали роботу із літературними джерелами, наприклад: «За Програмою розвитку дитини «Я у Світі» проаналізуйте психологічну характеристику раннього віку. Письмово сформулюйте не менше 10 особливостей раннього дитинства як вікового періоду», «Ознайомтесь з всесвітньо відомою книгою Б. Спока «Дитина і догляд за нею». 3 якими принциповими положеннями Спока ви згідні, а з якими - ні? Чому?», «Законспектуйте основні положення методики М. Ібука за книгою «Після трьох вже пізно», «Ознайомтесь з рекомендаціями для молодих матерів О. Нікітіного та Л. Павлової та на основі опрацьованого матеріалу складіть «Пам'ятку молодої матері» 3 догляду за дитиною перших місяців життя».

Для удосконалення педагогічної майстерності ми пропонували студентам такі завдання: підберіть та продемонструйте забавлянку, казку, вірш, пісню, гімнастику пробудження, елементи масажу для дітей раннього віку тощо.

Найцікавішими були завдання практичного характеру, а саме: виготовіть та продемонструйте Монтессорі-матеріал для дітей раннього віку; виготовіть 2 «біти знань» за усіма вимогами для дітей раннього віку; виготовіть дидактичний 
посібник для дітей раннього віку на липучках і розробіть до нього методичні рекомендації та ін.

Робота зі здобувачами вищої освіти на лабораторних заняттях дещо відрізнялась від роботи на практичних тому, що мала більш практичний та творчий характер. Зокрема, під час лабораторних занять майбутні вихователі: проводили заняття в аудиторії з усіма наочними матеріалами; проводили спостереження за дитиною раннього віку та здійснювали оцінку іiі розвитку; виготовляли лепбуки та бізіборди, проводили їх презентацію у групі; готували портфоліо для роботи в групах дітей раннього віку.

За період вивчення курсу «Педагогіка раннього дитинства» здобувачі вищої освіти оволоділи такими вміннями як: визначення конкретних завдань виховання дітей раннього віку; добірка методів та форм організації навчальновиховного процесу в групах дітей раннього віку дошкільного закладу; налагодження стосунків 3 дітьми та їх батьками під час педагогічної практики; використання досягнення педагогічної науки i практики в роботі 3 дітьми раннього віку; проведення найпростіших досліджень 3 метою вивчення особистості дитини раннього віку; визначення завдань для роботи 3 дітьми раннього віку; визначення змісту роботи з дітьми раннього віку; упорядкування приблизного режиму дня; проведення діагностики з виявлення особливостей розвитку дітей раннього віку; розробка рекомендації для педагогів і батьків 3 виховання дітей раннього віку.

Висновки і перспективи подальших розвідок. У результаті дослідження визначено, що для сучасної вищої освіти пріоритетом стає підготовка фахівця інноваційного типу, який здатний реалізувати освітні стандарти та впроваджувати нові освітні технології.

Виявлено особливість професійного становлення майбутнього вихователя закладу дошкільної освіти, яка передбачає не тільки оволодіння певною сукупністю знань, умінь та навичок, але і особистісне самовдосконалення та активізацію професійної позиції здобувача вищої освіти, виховання у нього професійних якостей, світоглядних позицій, переконань, творчих здібностей та професійної гнучкості.

За підсумками нашого дослідження готовність до роботи, ми розглядаємо як здатність здійснювати роботу 3 дітьми раннього віку та сформованість у здобувачів вищої освіти професійних якостей вихователя, що дозволяють ефективно забезпечувати педагогічну діяльність 3 дітьми цієї вікової категорії.

\section{СПИСОК ВИКОРИСТАНИХ ДЖЕРЕЛ}

Куліш, Р. (2014). Підготовка майбутніх фахівців дошкільної освіти до професійної діяльності. Науковий вісник МНУ імені В.О.Сухомлинського. Педагогічні науки. Випуск 1.45 (106). сс. 73-77.

Танько, Т. (2004). Теорія та практика музично-педагогічної підготовки майбутніх вихователів дошкільних закладів у педагогічних університетах. Доктор педагогічних наук. Харківський державний педагогічний університет імені Г.С. Сковороди.

Поніманська, Т. (2012). Модель системи підготовки студентів до гуманістичного виховання дітей старшого дошкільного віку. Оновлення змісту, форм та методів навчання і виховання в закладах освіти. Випуск 5 (48). с. 48. 
Інноватика у вихованні. Випуск 12. 2020.

Жаровцева, Т. (2006). Теоретико-методичні засади підготовки фахівиів дошкільної освіти до роботи з неблагополучними сім'ями: монографія. Одеса : ПНЦ АПН України - СВД М. П. Черкасов, 367 с.

\title{
REFERENCES
}

Kulish, R. (2014). Pidhotovka maibutnikh fakhivtsiv doshkilnoi osvity do profesiinoi diialnosti [Training of future preschool education specialists for professional activity]. Naukovyi visnyk MNU imeni V.O.Sukhomlynskoho. Pedahohichni nauky. Vypusk 1.45 (106). ss. 73-77. [in Ukrainian]

Tanko, T. (2004). Teoriia ta praktyka muzychno-pedahohichnoi pidhotovky maibutnikh vykhovateliv doshkilnykh zakladiv $u$ pedahohichnykh universytetakh [Theory and practice of music-pedagogical training of future educators of preschool institutions in pedagogical universities]. Doktor pedahohichnykh nauk. Kharkivskyi derzhavnyi pedahohichnyi universytet imeni H.S. Skovorody. [in Ukrainian]

Ponimanska, T. (2012). Model systemy pidhotovky studentiv do humanistychnoho vykhovannia ditei starshoho doshkilnoho viku [Model of system of preparation of students for humanistic education of children of senior preschool age]. Onovlennia zmistu, form ta metodiv navchannia i vykhovannia v zakladakh osvity. Vypusk 5 (48). s. 48. [in Ukrainian]

Zharovtseva, T. (2006). Teoretyko-metodychni zasady pidhotovky fakhivtsiv doshkilnoi osvity do roboty z neblahopoluchnymy simiamy: monohrafiia [Theoretical and methodical bases of preparation of experts of preschool education to work with disadvantaged families: monograph]. Odesa : PNTs APN Ukrainy - SVD M. P. Cherkasov, 367 s. [in Ukrainian]

\section{READINESS OF FUTURE EDUCATORS TO THE WORK WITH EARLY-AGED CHILDREN}

\author{
Olha Shadiuk \\ Candidate of Pedagogical Sciences, Associate Professor, \\ Associate Professor at the Department of \\ prof. Ponimanska T. I.Pedagogy and Psychology \\ (preschool and correctional), \\ Rivne State University for the Humanities, \\ Rivne, Ukraine. \\ ORCID: 0000-0001-6120-7759, \\ e-mail: olgapad@ukr.net
}

\begin{abstract}
The article theoretically substantiates the problem of preparing future educators for professional activities, in particular for working with early-aged children. Modern approaches to vocational and preschool education are considered. The essence of the concept of "professional training" and "readiness" is defined and specified. Peculiarities of teaching the discipline "Early Childhood Pedagogy" for students of the first level of higher education, specialty 012 "Preschool Education" were analyzed. The issues of professional training of future educators for professional activities have been reflected in many studies. At the same time, the problem of readiness of future educators to work with early-aged children in a modern preschool institution remains insufficiently developed.
\end{abstract}


One of the priority areas of modernization and renewal of preschool education is to improve the training of teachers, including educators for preschool education. At the present stage of development of society for vocational education has become particularly relevant problem of finding ways to develop and improve the system of training teachers to work in a modern preschool institution, and especially to work with young children. The formation of the readiness of future educators to work with early-aged children will be most effective in the process of studying the discipline 'Early Childhood Pedagogy", which provides a comprehensive approach to the formation of certain knowledge and practical skills for working with young children.

The main tasks of forming the readiness of future educators to work with earlyaged children are: involving applicants for higher education in future work with young children, showing a lasting interest in it; systematization, consolidation, deepening and expansion of theoretical knowledge and practical skills of future educators; the formation of awareness of the self-worth of early childhood as a foundation for the formation of personality.

Key words: readiness, higher education seeker, future educators, early-aged children, professional training.

Стаття надійшла до редакиії 22. 09. 2020 р. 